\title{
Transaction cost analysis in availing benefits from the Governmental programmes by Scheduled Caste and Scheduled Tribe farmers in Karnataka
}

See end of the paper for authors' affiliations

Correspondence to :

S. Anitha

Department of Agricultural

Economics, University of

Agricultural Sciences,

G.K.V.K., Bengaluru

(Karnataka) India

Paper History :

Received : 02.03.2018;

Revised : 25.04.2018,

Accepted : 02.05.2018
ABSTRACT : Transaction costs (TC) are the costs involved in making an economic exchange. It includes search and information costs, bargaining costs and policing and enforcement costs. This study mainly focused on estimation of comparative transaction cost incurred in availing the Governmental benefits by the Scheduled Castes and Scheduled Tribe (SC/ST) farmers in hilly zone of Karnataka. A sample of 35 SC/ST farmers from Gram Panchayaths of Good Governance (GpGG) and Gram Panchayaths of Modest Governance (GpMG) of Sakleshpur Hassan district of Karnataka had chosen for analysis. The results revealed that the benefits received by SC/ST farmers from Governmental programmes by GpGG farmer is Rs. 17356, by participating in 8 governmental programmes and GpMG farmer gain Rs. 10764 by participating 6 Governmental programmes. The average transaction cost of Rs. 304 per programme was spent in GpGG, whereas Rs. 307 per programme was paid in GpMG. For every rupee of transaction cost incurred, the total benefit from governmental programmes increased by Rs. 2.8. The percentage of transaction cost varies from programme to programme (one to thirty three \%). The opportunity cost of labour accounts to 32 per cent of in GpGG whereas it is higher in GpMG 37 per cent. Expenditure incurred in obtaining documents in both the Governance is at par that is 33 to 34 per cent, whereas rent paid exclusively to avail the benefits is comparatively higher in GpGG (35\%) than GpMG (29\%). Irrespective of Governance the transaction cost remains constant. Panchayath Raj should be well Governed to reduce the transaction cost and inclusion and exclusion errors.

KEY WORDS : Transaction cost, Governance, Panchayath Raj, Benefits from Governmental programmes, SC/ST farmers

How To Cite This Paper : Anitha, S. and Ananth, G. S. (2018). Transaction cost analysis in availing benefits from the Governmental programmes by Scheduled Caste and Scheduled Tribe farmers in Karnataka. Res. J. Agric. Eco. \& Stat., 9 (2) : 257-265, DOI : 10.15740/HAS/IRJAES/9.2/257-265. Copyright@ 2018:Hind Agri-Horticultural Society. 